\title{
Pemilihan Supplier Bahan Baku Partikel Dengan Metode AHP Dan Promethee
}

\author{
Ratri Wulandari \\ Jurusan Teknik Industri, Fakultas Teknik, Universitas Muhammadiyah Malang \\ Jl. Raya Tlogomas 246 Malang \\ Sure; : ra3wulandari011@gmail.com
}

\begin{abstract}
The problem of choosing a supplier becomes very important to do a company to be able to meet consumer demand quickly and with quality. So far, the company has not implemented the supplier selection procedures and selection criteria not yet have a supplier. The method can be completed with the supplier selection criteria is the AHP method is used to determine the weights of criteria that have been corporations and PROMETHEE method used to determine the performance of the alternative. The purpose of this research is to identify the criteria used in the selection of a supplier company and determine the weight of these criteria and get ranked supplier to obtain the best supplier. The selected criteria in the selection of the supplier company is quality with a weight of 0.19, with a weight of 0.17 delivery, performance history with a weighting of 0.06 , the price with a weighting of 0.36, communication system with a weighting of 0.06, the operating control with weights of 0.05, attitudes supplier with a weighting of 0.04 and a geographical location with a weight of 0.08 where as criteria rank order supplier is UD. TL as the first rank with a net value of flow for 0.254, UD. $S D$ as the second rank with a value of 0.144 and a net flow PT.KTI as third with a net flow value of -0.397 .
\end{abstract}

Keywords: Supplier Selection, AHP, PROMETHEE

\begin{abstract}
Abstrak
Masalah memilih supplier menjadi sangat penting dilakukan sebuah perusahaan untuk dapat memenuhi permintaan konsumen secara cepat dan berkualitas. Metode yang dapat menyelesaikan pemilihan supplier dengan kriteria-kriteria adalah metode AHP dan PROMETHEE. Tujuan penulisan makalah ini adalah mengidentifikasi kriteria yang digunakan perusahaan dalam pemilihan supplier dan menentukan bobot kriteria tersebut serta mendapatkan peringkat supplier sehingga didapatkan supplier terbaik. Kriteria-kriteria yang dipilih perusahaan dalam pemilihan supplier adalah quality dengan bobot sebesar 0.19, delivery dengan bobot sebesar 0.17, performance history dengan bobot sebesar 0.06, price dengan bobot sebesar 0.36, communication system dengan bobot sebesar 0.06, operating control dengan bobot sebesar 0.05, attitudes supplier dengan bobot sebesar 0.04 dan geographical location dengan bobot kriteria sebesar 0.08 sedangkan urutan ranking supplier adalah UD. TL sebagai peringkat pertama dengan nilai net flow sebesar 0.254, UD. SD sebagai peringkat kedua dengan nilai net flow sebesar 0.144 dan PT.KTI sebagai peringkat ketiga dengan nilai net flow sebesar -0.397
\end{abstract}

Kata Kunci : Pemilihan Supplier, AHP, PROMETHEE

\section{Pendahuluan}

Pemilihan supplier sangat penting dilakukan oleh perusahaan untuk dapat meningkatkan rantai pasok yang baik dan mendapatkan kualitas mutu produk yang baik pula. Permasalahan pada pihak supplier selama ini adalah, semua supplier belum mampu memenuhi semua kriteria yang ditetapkan pihak perusahaan. Umumnya supplier 
mempunyai kinerja yang baik hanya dalam satu sisi kriteria sedangkan di sisi lain belum memenuhi dan kurang dalam hal sisi lainnya. Di sisi lain perusahaan dan industri manufaktur selalu menginginkan performansi kriteria supplier dapat memenuhi standar nilai kriteria yang ditargetkan perusahaan tersebut. Standar nilai tersebut dibutuhkan sehingga terjadi keseimbangan rantai pasok yang diharapkan menjadi mitra bisnis yang saling menguntungkan dan terjadi secara terus-menerus. Kegiatan memilih supplier bisa memakan waktu dan sumber daya yang tidak sedikit apalagi supplier yang dimaksud adalah supplier utama. Proses memilih supplier merupakan suatu pengambilan keputusan untuk memilih alternatif. Tabucanon [1] mengatakan bahwa proses pengambilan keputusan adalah pemilihan suatu alternatif dari berbagai alternatif sehingga menghasilkan pilihan terbaik berdasarkan beberapa kriteria optimasi.

CV. Mitra Jaya merupakan perusahaan yang memproduksi mesin penetas telur yang berada di Kota Malang. CV. Mitra Jaya belum memiliki prosedur pemilihan supplier dan kriteria-kriteria yang sesuai dengan standar perusahaan dalam memilih supplier. Pemilihan supplier yang dilakukan manajer perusahaan saat ini adalah survei langsung ke pabrik kayu partikel dan melakukan perbandingan harga. Saat ini perusahaan memiliki 3 supplier yang memasok bahan baku partikel berukuran $122 \mathrm{~cm}$ x $244 \mathrm{~cm}$ x 9 $\mathrm{mm}$ yang digunakan untuk semua tipe mesin. Penelitian ini bertujuan untuk mengindentifikasi kriteria pemilihan supplier dan menentukan bobot prioritasnya serta menentukan urutan ranking supplier.

Menurut Suryadi and Ramdhani [2] salah satu metode yang dapat menyelesaikan pengambilan keputusan dengan kriteria-kriteria adalah AHP (Analytical Hierarchy Process) dan PROMETHEE (Preference Ranking Organization Method for Enrichment Evaluation). AHP merupakan suatu model pendukung keputusan yang dikembangkan oleh Thomas L. Saaty. Model pendukung keputusan ini akan menguraikan masalah multi faktor atau multi kriteria yang kompleks menjadi suatu hirarki[3]. AHP menawarkan penyelesaian masalah keputusan yang melibatkan seluruh sumber kerumian seperti beragamnya kriteria, hal ini dimungkinkan karena AHP cukup mengandalkan pada intuisi sebagai input utamanya namun intuisi harus datang dari pengambilan keputusan yang cukup informasi dan memahami masalah pangambilan keputusan yang dihadapi [4]. PROMETHEE adalah suatu metode penentuan urutan (prioritas) dalam analisis multikriteria [5]. Menurut Triyanti and Gadis [6] metode PROMETHEE cukup baik dalam memperhitungkan karakteristik dari data. Hasil dari penelitian Harsono, et al. [7] tersebut menyimpulkan bahwa metode ini dapat memberikan cara penilaian pemasok secara terstruktur dan transparan, dan tidak hanya mempertimbangkan bobot dari kriteria akan tetapi juga jenis keputusan yang harus diambil dari masing-masing kriteria.

\section{Metode Penelitian}

Pengolahan data dilakukan dengan lima tahapan, yaitu tahap pendahuluan / identifikasi masalah, pengumpulan data, pengolahan data, analisis data, dan penarikan kesimpulan. Pada tahap pendahuluan yang merupakan langkah awal dari penelitian dengan melakukan studi lapangan dan studi pustaka. Tahap pengumpulan data dilakukan untuk mengumpulkan data-data yang diperlukan untuk penelitian. Data yang dikumpulkan berupa data primer yakni data supplier, kriteria pemilihan supplier, kuisioner matriks perbandingan berpasangan, kuisioner tipe dan parameter fungsi preferensi kriteria pemilihan supplier maupun data sekunder yakni profil perusahaan.

Pengolahan data merupakan proses untuk memperoleh data ringkasan berdasarkan kelompok data mentah pada semua data yang telah dikumpulkan pada pengumpulan data. Pengolahan data tersebut meliputi metode AHP dan PROMETHEE dimana metode AHP digunakan untuk menentukan bobot kriteria yang dimulai dengan 
mendefinisikan masalah dan menentukan solusi yang diinginkan, membuat struktur hirarki, melakukan perbandingan berpasangan, membuat matriks normalisasi setiap kriteria dengan AHP, penentuan bobot setiap kriteria dan uji konsistensi sedangkan metode PROMETHEE digunakan untuk mengetahui urutan ranking supplier yang dimulai dengan penentuan derajat preferensi dengan PROMETHEE I, penentuan indeks preferensi, perhitungan leaving flow dan entering flow, perhitungan PROMETHEE II dan penentuan ranking supplier[8].

Mendefinisikan masalah dan menentukan solusi yang diinginkan dilakukan dengan mendeskripsikan masalah yang terkait serta solusi yang ingin dicapai kemudian menyusunnya dalam bentuk struktur hirarki mulai dari level tujuan, kriteria sampai pada level alternatif. Selanjutnya, melakukan perbandingan berpasangan dengan membuat matriks perbandingan berpasangan yang telah diperoleh dari hasil pengisian kuisioner matriks perbandingan berpasangan dan menormalisasi setiap kriteria untuk memperoleh normalisasi matriks. Perhitungan normalisasi kriteria dilakukan pada persamaan 1 sebagai berikut:

Dimana:

$$
\mathrm{Ci}, \mathrm{Cj}]=\frac{C i j}{\sum K l}
$$

$[\mathrm{Ci}, \mathrm{Cj}]=$ kriteria $i$ dengan kriteria $j$

$\mathrm{Cij}=$ nilai matriks perbandingan berpasangan AHP kriteria $i$ dengan kriteria $j$

$\sum K l \quad=$ Total penjumlahan kolom kriteria $l$

Penentuan bobot setiap kriteria dilakukan dengan menjumlahkan nilai-nilai dari setiap baris matriks yang telah dinormalisasi dan membaginya dengan jumlah elemen untuk mendapatkan nilai rata-rata. Sehingga akan diperoleh bobot setiap kriteria. Penentuan bobot tersebut didasarkan pada semakin besar nilai bobot yang dihasilkan maka semakin tinggi prioritas kriteria tersebut. Jumlah bobot semua kriteria harus sama dengan 1. Untuk mengetahui seberapa baik nilai ketidak konsistensian yang ada. Perhitungan konsistensi rasio dapat dilakukan pada persamaan 2 sebagai berikut:

$$
\mathrm{CR}=\mathrm{CI} / \mathrm{RI}
$$

Jika nilai yang diperoleh lebih dari $10 \%$ maka penilaian dari judgment harus diperbaiki/diulang. Namun jika rasio konsistensi kurang atau sama dengan 0.1 (10\%) maka penilaian dapat diterima.

Derajat preferensi didapatkan sesuai dengan data kuisioner tipe dan parameter fungsi preferensi masing-masing kriteria. Perhitungan ini dilakukan dengan pengurangan nilai skala penilaian alternatif satu dengan yang lainnya kemudian di lakukan untuk semua alternatif sedangkan indeks preferensi ditentukan dengan menggunakan bobot dari AHP kemudian dikalikan dengan masing-masing nilai fungsi preferensi dan derajat preferensi setiap kriteria. Indeks preferensi dilakukan dengan membandingkan seluruh alternatif. Perhitungan indeks preferensi dapat dilakukan dengan persamaan 3 sebagai berikut:

$$
\pi(\mathrm{a}, \mathrm{b})=\frac{1}{k} \sum_{h=1}^{k} p_{h}(a, b)
$$

Perhitungan selanjutnya adalah menghitung nilai leaving flow dengan menjumlahkan nilai indeks preferensi setiap alternatif $a, x$ dibagi dengan jumlah alternatif. Perhitungan leaving flow dapat dilakukan dengan persamaan 4 sebagai berikut:

$$
\Phi^{+}(a)=\frac{1}{\mathrm{n}-1} \sum_{\mathrm{x} \in \mathrm{a}} \wp(\mathrm{a}, \mathrm{x})
$$


Sedangkan perhitungan entering flow dilakukan dengan menjumlahkan nilai indeks preferensi setiap alternatif $\mathrm{x}$, a dibagi dengan jumlah alternatif yang ada. Perhitungan entering flow dapat dilakukan dengan persamaan 5 sebagai berikut:

$$
\Phi^{-}(a)=\frac{1}{\mathrm{n}-1} \sum_{\mathrm{x} \in \mathrm{a}} \wp(\mathrm{X}, \mathrm{a})
$$

Pada perhitungan nilai leaving flow dan entering flow, jika hasil perhitungan didapatkan nilai imcomparable maka dilakukan perhitungan PROMETHEE II dengan menghitung nilai net flow. Perhitungan net flow dapat dilakukan dengan persamaan 6 sebagai berikut:

$$
\Phi(\mathrm{a})=\Phi^{+}(\mathrm{a})-\Phi^{-}(\mathrm{a})
$$

Hasil perhitungan pada nilai net flow memberikan nilai untuk setiap alternatif dan penentuan ranking supplier diperoleh dengan mengurutkan nilai net flow terbesar sampai terkecil. Hasil urutan supplier tertinggi diputuskan bahwa alternatif yang memiliki nilai net flow terbesar merupakan supplier terbaik untuk dipilih.

Pada tahap analisis, dilakukan analisis dari hasil pengolahan data. Sebagai tahap akhir, yaitu penarikan kesimpulan hasil penelitian yang dilakukan.

\section{Hasil dan Pembahasan}

Penelitian ini dilakukan di CV. Mitra Jaya yang terletak di Kota Malang. Visi perusahaan adalah menjadikan Mitra Jaya sebagai badan usaha yang berkarya untuk membangun bangsa sedangkan misi perusahaan adalah menjadi perusahaan Industri dan komponen untuk bidang penetasan telur yang akan terus berusaha untuk mengembangkan perusahaan tanpa mengenal menyerah.

\subsection{Kriteria Pemilihan Supplier}

Identifikasi kriteria pemilihan supplier berdasarkan hasil wawancara dengan perusahaan dan beberapa studi pustaka yang mendukung. Hasil kriteria pemilihan supplier yang diperoleh pada Tabel 1.

\begin{tabular}{|c|c|c|c|}
\hline No. & Kode & Kriteria & Deskripsi \\
\hline 1. & $\mathrm{C}_{1}$ & Quality & $\begin{array}{l}\text { Kemampuan supplier dalam memenuhi spesifikasi kualitas } \\
\text { secara konsisten terhadap bahan baku yang dipasok }\end{array}$ \\
\hline 2. & $\mathrm{C}_{2}$ & Delivery & $\begin{array}{l}\text { Ketepatan waktu pengiriman dari tanggal waktu yang } \\
\text { telah dijanjikan (date promise) }\end{array}$ \\
\hline 3. & $\mathrm{C}_{3}$ & $\begin{array}{l}\text { Performance } \\
\text { History }\end{array}$ & Posisi perusahaan/reputasi dalam dunia industri \\
\hline 4. & $\mathrm{C}_{4}$ & Price & Harga yang ditawarkan oleh masing-masing supplier \\
\hline 5. & $\mathrm{C}_{5}$ & $\begin{array}{l}\text { Communication } \\
\text { System }\end{array}$ & Kemudahan dihubungi \\
\hline 6. & $\mathrm{C}_{6}$ & Operating Control & $\begin{array}{l}\text { Kemampuan supplier dalam mengendalikan persediaan } \\
\text { bahan baku maupun pelaporan ketersediaan bahan baku }\end{array}$ \\
\hline 7. & $\mathrm{C}_{7}$ & Attitudes Supplier & $\begin{array}{l}\text { Sikap/perilaku pemasok termasuk negosiasi dan tanggap } \\
\text { dalam perubahan permintaan sewaktu-waktu }\end{array}$ \\
\hline 8. & $\mathrm{C}_{8}$ & $\begin{array}{l}\text { Geographical } \\
\text { Location }\end{array}$ & Jarak pemasok dengan lokasi pabrik \\
\hline
\end{tabular}

Tabel 1 Kriteria Pemilihan Supplier 
Pada pemilihan kriteria diatas, didasarkan perusahaan sesuai dengan spesifikasi bahan baku yakni partikel dan studi literatur yang didapatkan dari beberapa kriteria oleh Dickson [9]. Terdapat 8 kriteria yang telah dipilih perusahaan yang dianggap dapat menjadi kriteria penilaian perusahaan dalam memilih supplier. Kriteria ini dianggap dapat mewakili semua penilaian terhadap supplier sehingga perusahaan mampu menilai performansi masing-masing supplier.

\subsection{Analytical Hierarchy Process (AHP)}

Pemilihan supplier bahan baku partikel di perusahaan CV. Mitra Jaya perlu dilakukan untuk mengetahui performansi dan mengetahui supplier terbaik untuk memasok bahan baku partikel yang menjadi bahan baku utama mesin penetas telur. Pemilihan supplier dilakukan dengan menentukan kriteria-kriteria yang dipilih perusahaan sehingga diperoleh bobot kriteria yang menjadi prioritas perusahaan[10]. Dalam hal ini, penentuan bobot kriteria-kriteria didapatkan menggunakan metode AHP kemudian dilanjutkan dengan menentukan supplier terbaik sehingga diperoleh alternatif untuk menjadi supplier terbaik dalam memasok bahan baku partikel.

Hirarki pemilihan supplier bahan baku partikel diawali dengan tujuan umum sampai kriteria dan alternatif-alternatifnya. Hirarki pemilihan supplier tersebut dapat dilihat pada Gambar 1:

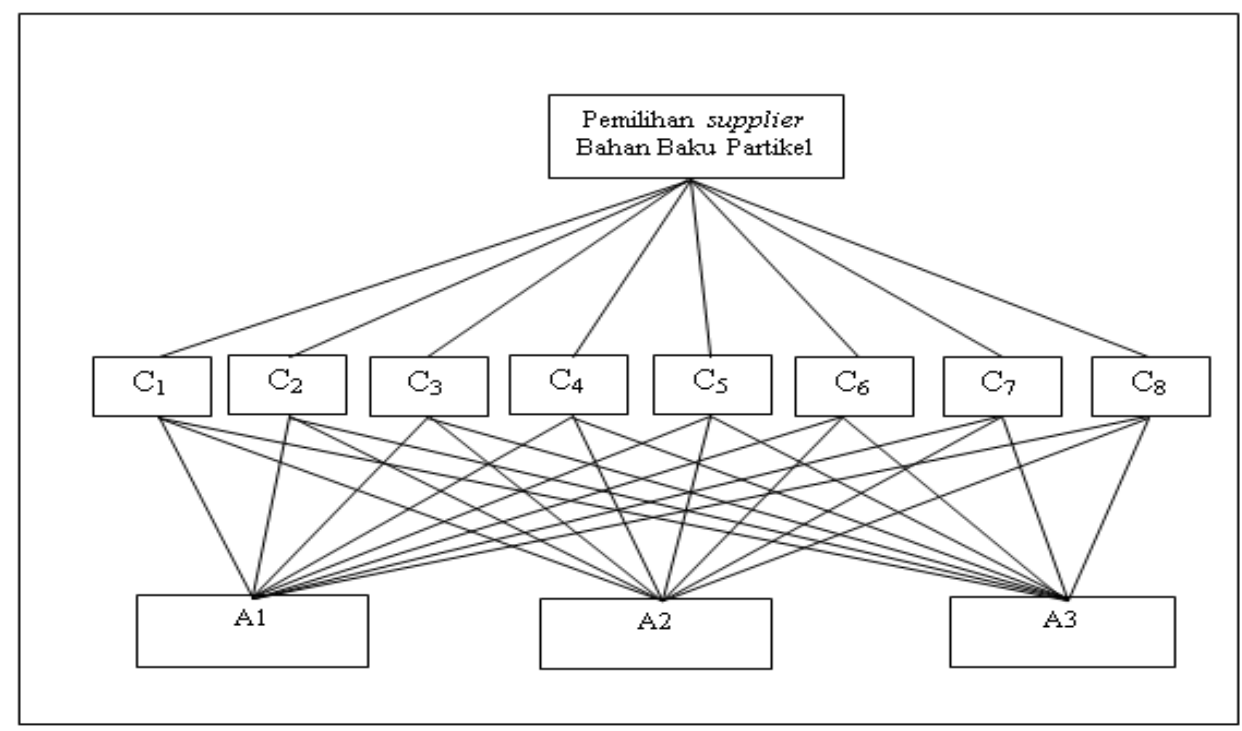

Gambar 1. Struktur Hirarki Pemilihan Supplier

Tahap selanjutnya adalah membuat matriks perbandingan berpasangan. Tahap ini dilakukan dengan membuat matriks perbandingan berpasangan yang telah diperoleh dari hasil pengisian kuisioner yang telah dilakukan oleh manajer perusahaan dan menormalisasi matriks perbandingan berpasangan tersebut.

Untuk membuat matriks normalisasi, dilakukan perhitungan skala penilaian perbandingan berpasangan kriteria yang dibagi dengan total kriteria itu sendiri. Perhitungan matriks normalisasi sesuai dengan persamaan 1 dan didapatkan hasil pada Tabel 3.

Dalam metode AHP, sebuah kriteria dianggap memiliki prioritas tertinggi jika bobot yang dihasilkan memiliki nilai yang besar dari nilai kriteria yang lainnya. Penyusunan prioritas dilakukan untuk tiap elemen masalah pada tingkat hirarki. Proses ini akan menghasilkan bobot atau kontribusi kriteria terhadap pencapaian tujuan. Prioritas ditentukan oleh kriteria yang mempunyai bobot paling tinggi. Penentuan bobot 
prioritas dilakukan dari penjumlahan hasil matriks normalisasi pada Tabel 3 dan membagi nya dengan jumlah kriteria (n). Hasil perhitungan dapat dilihat pada Tabel 4.

Tabel 2 Matriks Perbandingan Berpasangan

\begin{tabular}{ccccccccc}
\hline Kriteria & C1 & C2 & C3 & C4 & C5 & C6 & C7 & C8 \\
\hline C1 & 1 & 1 & 5 & $1 / 4$ & 5 & 5 & 5 & 3 \\
C2 & 1 & 1 & 5 & $1 / 3$ & 3 & 3 & 5 & 3 \\
C3 & $1 / 5$ & $1 / 5$ & 1 & $1 / 7$ & 3 & 1 & 2 & $1 / 3$ \\
C4 & 4 & 3 & 7 & 1 & 5 & 5 & 7 & 5 \\
C5 & $1 / 5$ & $1 / 3$ & $1 / 3$ & $1 / 5$ & 1 & 1 & 1 & 3 \\
C6 & $1 / 5$ & $1 / 3$ & 1 & $1 / 5$ & 1 & 1 & 1 & $1 / 3$ \\
C7 & $1 / 5$ & $1 / 5$ & $1 / 2$ & $1 / 7$ & 1 & 1 & 1 & $1 / 3$ \\
C8 & $1 / 3$ & $1 / 3$ & 3 & $1 / 5$ & $1 / 3$ & 3 & 3 & 1 \\
Total & 7.13 & 6.40 & 22.83 & 2.47 & 19.33 & 20.00 & 25.00 & 16.00 \\
\hline
\end{tabular}

Tabel 3 Matriks Normalisasi

\begin{tabular}{ccccccccc}
\hline Kriteria & C1 & C2 & C3 & C4 & C5 & C6 & C7 & C8 \\
\hline C1 & 0.14 & 0.16 & 0.22 & 0.10 & 0.26 & 0.25 & 0.20 & 0.19 \\
C2 & 0.14 & 0.16 & 0.22 & 0.14 & 0.16 & 0.15 & 0.20 & 0.19 \\
C3 & 0.03 & 0.03 & 0.04 & 0.06 & 0.16 & 0.05 & 0.08 & 0.02 \\
C4 & 0.56 & 0.47 & 0.31 & 0.41 & 0.26 & 0.25 & 0.28 & 0.31 \\
C5 & 0.03 & 0.05 & 0.01 & 0.08 & 0.05 & 0.05 & 0.04 & 0.19 \\
C6 & 0.03 & 0.05 & 0.04 & 0.08 & 0.05 & 0.05 & 0.04 & 0.02 \\
C7 & 0.03 & 0.03 & 0.02 & 0.06 & 0.05 & 0.05 & 0.04 & 0.02 \\
C8 & 0.05 & 0.05 & 0.13 & 0.08 & 0.02 & 0.15 & 0.12 & 0.06 \\
\hline
\end{tabular}

Dari hasil yang telah dilakukan, didapatkan bahwa kriteria yang paling berpengaruh terhadap pemilihan supplier adalah kriteria harga $\left(\mathrm{C}_{4}\right)$ dengan bobot terbesar, yaitu 0,36 sedangkan kriteria yang berpengaruh paling rendah adalah attitudes supplier $\left(\mathrm{C}_{7}\right)$ dengan bobot sebesar 0.04. Setelah dilakukan perhitungan eigen vector atau bobot prioritas masing-masing kriteria maka dilakukan perhitungan untuk matriks perbandingan berpasangan terhadap bobot kriteria yang telah didapatkan pada Tabel 4 untuk mendapatkan nilai normalisasi terbobot.

Tabel 4 Bobot Prioritas Tiap Kriteria

\begin{tabular}{|c|c|c|c|c|c|c|c|c|c|c|}
\hline Kriteria & C1 & C2 & C3 & C4 & C5 & C6 & C7 & C8 & Jumlah & Bobot \\
\hline C1 & 0.14 & 0.16 & 0.22 & 0.10 & 0.26 & 0.25 & 0.20 & 0.19 & 1.51 & 0.19 \\
\hline C2 & 0.14 & 0.16 & 0.22 & 0.14 & 0.16 & 0.15 & 0.20 & 0.19 & 1.34 & 0.17 \\
\hline C3 & 0.03 & 0.03 & 0.04 & 0.06 & 0.16 & 0.05 & 0.08 & 0.02 & 0.47 & 0.06 \\
\hline C4 & 0.56 & 0.47 & 0.31 & 0.41 & 0.26 & 0.25 & 0.28 & 0.31 & 2.84 & 0.36 \\
\hline C5 & 0.03 & 0.05 & 0.01 & 0.08 & 0.05 & 0.05 & 0.04 & 0.19 & 0.50 & 0.06 \\
\hline C6 & 0.03 & 0.05 & 0.04 & 0.08 & 0.05 & 0.05 & 0.04 & 0.02 & 0.37 & 0.05 \\
\hline C7 & 0.03 & 0.03 & 0.02 & 0.06 & 0.05 & 0.05 & 0.04 & 0.02 & 0.30 & 0.04 \\
\hline C8 & 0.05 & 0.05 & 0.13 & 0.08 & 0.02 & 0.15 & 0.12 & 0.06 & 0.66 & 0.08 \\
\hline \multicolumn{10}{|c|}{ Total } & 1.00 \\
\hline
\end{tabular}


Tahap selanjutnya adalah uji konsistensi hirarki. Jika tidak memenuhi dengan CR $<0,1$ maka penilaian harus diulang kembali. Pengukuran AHP adalah rasio konsistensi dengan melihat index konsistensi. Konsistensi yang diharapkan adalah yang mendekati sempurna agar menghasilkan keputusan yang mendekati valid. Perhitungan uji konsistensi dilakukan sebagai berikut:

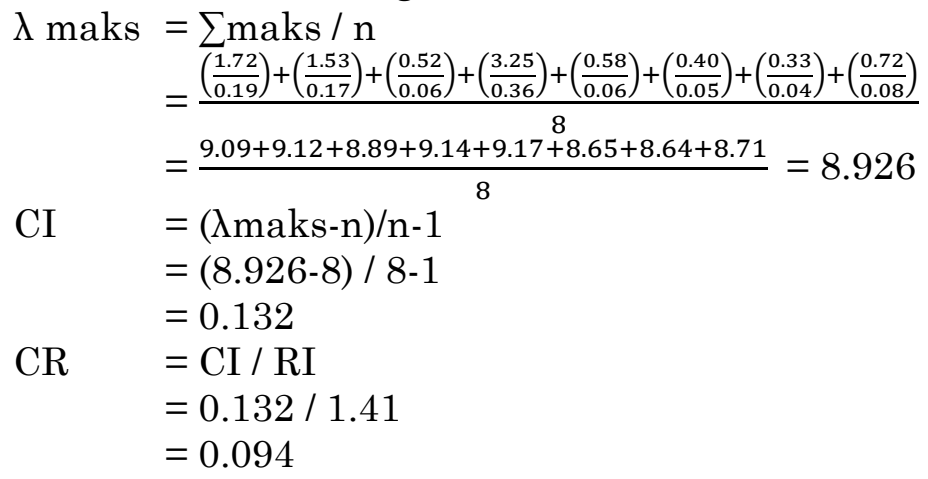

Hasil perhitungan dengan metode AHP didapatkan hasil yang menunjukkan nilai CR $<0.1$ yakni $0.094<0.1$ yang dapat disimpulkan bahwa penilaian matriks berpasangan masing-masing kriteria telah konsisten dan data matriks perbandingan serta bobot kriteria yang telah diperoleh dapat digunakan.

\subsection{Preferences Ranking Organization Method for Enrichment Evaluation (PROMETHEE)}

Dalam metode PROMETHEE menyediakan enam rekomendasi tipe preferensi untuk masing-masing kriteria. Rekomendasi tipe preferensi tersebut menyediakan banyak fungsi yang dapat mengakomodasi berbagai karekteristik dari suatu data. Sebelumnya, telah ditentukan tipe preferensi dan nilai preferensi masing-masing alternatif terhadap kriteria. Hasil penentuan tipe dan parameter fungsi preferensi dapat dilihat pada Tabel 5 .

Metode PROMETHEE dalam masalah tersebut digunakan untuk memilih supplier bahan baku partikel. Bobot yang akan digunakan dalam metode tersebut telah didapatkan dari metode AHP sebelumnya. Langkah metode PROMETHEE dalam memilih supplier dilakukan penentuan derajat preferensi, penentuan index preferensi, perhitungan leaving flow dan entering flow, perhitungan net flow serta menentukan urutan ranking supplier. Derajat preferensi dilakukan dengan cara mengevaluasi nilai deviasi mutlak terhadap parameter dan tipe kriteria yang sesuai untuk setiap kriteria berdasarkan fungsi maksimasi atau minimasi. Penentuan derajat preferensi dilakukan pada masing-masing alternatif dibandingkan alternatif lainnya didasarkan pada Tabel 5 sehingga hasil perhitungan keseluruhan derajat preferensi dapat dilihat dalam Tabel 6 .

Pada perhitungan tersebut, indeks preferensi dihitung menggunakan persamaan 3 dan bobot dari metode AHP sehingga didapatkan hasil pada Tabel 7. Indeks preferensi ditentukan berdasarkan nilai hubungan outranking pada sejumlah kriteria dari masingmasing alternatif. Index preferensi digunakan untuk mennetukan nilai kekutan (leaving flow) dan nilai kelemahan (entering flow). Perhitungan ini didasarkan pada nilai indeks preferensi yang dilakukan dengan persamaan 4 dan persamaan 5, sebagai perhitungan net flow dilakukan dari hasil pengurangan nilai leaving flow dan entering flow semua alternatif yang ditujukkan pada persamaan 6 . Hasil perhitungan dapat dilihat pada Tabel 8 . 
Tabel 5 Tipe dan Parameter Fungsi Preferensi

\begin{tabular}{|c|c|c|c|c|c|c|c|c|c|}
\hline \multirow{2}{*}{$\begin{array}{l}\text { N } \\
\text { o. }\end{array}$} & \multirow{2}{*}{$\begin{array}{c}\text { Kod } \\
\text { e }\end{array}$} & \multirow[t]{2}{*}{ Kriteria } & \multicolumn{3}{|c|}{ Alternatif } & \multirow{2}{*}{$\begin{array}{c}\text { Kaidah } \\
\text { (Max/Mi } \\
\text { n) }\end{array}$} & \multirow{2}{*}{$\begin{array}{c}\text { Tipe } \\
\text { Kriteri } \\
\text { a }\end{array}$} & \multirow{2}{*}{$\begin{array}{c}\text { Paramete } \\
\mathbf{r}\end{array}$} & \multirow{2}{*}{$\begin{array}{l}\text { Satua } \\
\text { n }\end{array}$} \\
\hline & & & $\overline{A_{1}}$ & $\mathrm{~A}_{2}$ & $\mathrm{~A}_{3}$ & & & & \\
\hline 1. & $\mathrm{C}_{1}$ & Quality & 4 & 4 & 5 & Max & Linier & $\mathrm{p}=0.67$ & \\
\hline 2. & $\mathrm{C}_{2}$ & Delivery & 1 & 2 & 2 & Min & Linier & $\mathrm{p}=2$ & kali \\
\hline 3. & $\mathrm{C}_{3}$ & $\begin{array}{c}\text { Performance } \\
\text { History }\end{array}$ & 82 & 72 & 77 & Max & Quasi & $q=6.67$ & $\%$ \\
\hline 4. & $\mathrm{C}_{4}$ & Price & $\begin{array}{c}85.00 \\
0\end{array}$ & $\begin{array}{c}90.00 \\
0\end{array}$ & $\begin{array}{c}87.50 \\
0\end{array}$ & Min & Level & $\begin{array}{l}q=2500 \\
p=5.000\end{array}$ & $\mathrm{Rp}$ \\
\hline 5. & $\mathrm{C}_{5}$ & $\begin{array}{c}\text { Communicati } \\
\text { on System }\end{array}$ & 3 & 5 & 4 & $\operatorname{Max}$ & Linier & $\mathrm{p}=1.34$ & - \\
\hline 6. & $\mathrm{C}_{6}$ & $\begin{array}{c}\text { Operating } \\
\text { Control }\end{array}$ & 75 & 87 & 80 & Max & Quasi & $q=8$ & $\%$ \\
\hline 7. & $\mathrm{C}_{7}$ & $\begin{array}{l}\text { Attitudes } \\
\text { Supplier }\end{array}$ & 4 & 5 & 4 & Max & Quasi & $q=0.67$ & - \\
\hline 8. & $\mathrm{C}_{8}$ & $\begin{array}{l}\text { Geographical } \\
\text { Location }\end{array}$ & 18 & 47 & 72 & Min & Level & $\begin{array}{l}q=25 \\
p=50\end{array}$ & $\mathrm{~km}$ \\
\hline
\end{tabular}

Tabel 6 Penentuan Derajat Preferensi

\begin{tabular}{ccccccccc}
\hline Alternatif & C1 & C2 & C3 & C4 & C5 & C6 & C7 & C8 \\
\hline Bobot & 0.19 & 0.17 & 0.06 & 0.36 & 0.06 & 0.05 & 0.04 & 0.08 \\
$(\mathrm{~A} 1, \mathrm{~A} 2)$ & 0 & 0 & 1 & 0 & 0 & 0 & 0 & 0 \\
$(\mathrm{~A} 2, \mathrm{~A} 1)$ & 0 & 0.5 & 0 & 0.5 & 1 & 1 & 1 & 0.5 \\
$(\mathrm{~A} 1, \mathrm{~A} 3)$ & 0 & 0 & 0 & 0 & 0 & 0 & 0 & 0 \\
$(\mathrm{~A} 3, \mathrm{~A} 1)$ & 1 & 0.5 & 0 & 0 & 0.75 & 0 & 0 & 1 \\
$(\mathrm{~A} 2, \mathrm{~A} 3)$ & 0 & 0 & 0 & 0 & 0.75 & 0 & 1 & 0 \\
$(\mathrm{~A} 3, \mathrm{~A} 2)$ & 1 & 0 & 0 & 0 & 0 & 0 & 0 & 0 \\
\hline
\end{tabular}

Tabel 7 Index Preferensi

\begin{tabular}{cc}
\hline Alternatif & $\begin{array}{c}\text { Index } \\
\text { Preferensi }\end{array}$ \\
\hline$\left(\mathrm{A}_{1}, \mathrm{~A}_{2}\right)$ & 0.058 \\
$\left(\mathrm{~A}_{2}, \mathrm{~A}_{1}\right)$ & 0.450 \\
$\left(\mathrm{~A}_{1}, \mathrm{~A}_{3}\right)$ & 0.000 \\
$\left(\mathrm{~A}_{3}, \mathrm{~A}_{1}\right)$ & 0.403 \\
$\left(\mathrm{~A}_{2}, \mathrm{~A}_{3}\right)$ & 0.085 \\
$\left(\mathrm{~A}_{3}, \mathrm{~A}_{2}\right)$ & 0.189 \\
\hline
\end{tabular}

Tabel 8 Nilai leaving flow, entering flow dan Net Flow

\begin{tabular}{ccccc}
\hline Alternatif & Leaving & Entering & Net & Urutan \\
\hline A1 & 0.029 & 0.426 & -0.397 & 3 \\
A2 & 0.267 & 0.124 & 0.144 & 2 \\
A3 & 0.296 & 0.043 & 0.254 & 1 \\
\hline
\end{tabular}

Berdasarkan nilai Net Flow, yang mana semakin besar nilainya menunjukkan semakin besar prioritasnya. Dari perhitungan Net Flow yang telah dilakukan didapatkan perangkingan Dari Tabel 8, diperoleh posisi peringkat supplier adalah UD. TL $\left(\mathrm{A}_{3}\right)$ sebagai peringkat pertama dengan nilai net flow 
sebesar 0.254, kemudian UD. SD $\left(\mathrm{A}_{2}\right)$ sebagai peringkat kedua dengan nilai net flow sebesar 0.144 dan PT. KTI $\left(\mathrm{A}_{1}\right)$ sebagai peringkat ketiga atau terakhir dengan nilai net flow sebesar -0.397 .

\section{Simpulan}

Dari hasil penelitian yang telah dilakukan dapat disimpulkan kriteria-kriteria yang digunakan CV. Mitra Jaya dalam pemilihan supplier bahan baku partikel ukuran $122 \mathrm{~cm}$ x $244 \mathrm{~cm} \times 9 \mathrm{~mm}$ adalah quality dengan bobot kriteria sebesar 0.19, delivery dengan bobot kriteria sebesar 0.17 , performance history dengan bobot kriteria sebesar 0.06 , price dengan bobot kriteria sebesar 0.36 , communication system dengan bobot kriteria sebesar 0.06 , operating control dengan bobot kriteria sebesar 0.05 , attitudes supplier dengan bobot kriteria sebesar 0.04 dan geographical location dengan bobot kriteria sebesar 0.08. Hasil urutan ranking supplier didapatkan bahwa UD. TL sebagai peringkat pertama dengan nilai net flow sebesar 0.254, UD. SD sebagai peringkat kedua dengan nilai net flow sebesar 0.144 dan PT.KTI sebagai peringkat ketiga dengan nilai net flow sebesar -0.397.

\section{Referensi}

[1] M. T. Tabucanon, Multiple criteria decision making in industry vol. 8: Elsevier Science Ltd, 1988.

[2] K. Suryadi and M. A. Ramdhani, "Sistem Pendukung Keputusan: Suatu wacana struktural idealisasi dan implementasi konsep pengambilan keputusan," 2000.

[3] S. Avikal, P. Mishra, and R. Jain, "A Fuzzy AHP and PROMETHEE method-based heuristic for disassembly line balancing problems," International Journal of Production Research, vol. 52, pp. 1306-1317, 2014.

[4] S. Mulyono, "Teori Pengambilan Keputusan," Lembaga Penerbit Fakultas Ekonomi Universitas Indonesia, Jakarta, 1996.

[5] J.-P. Brans, P. Vincke, and B. Mareschal, "How to select and how to rank projects: The PROMETHEE method," European journal of operational research, vol. 24, pp. 228-238, 1986.

[6] V. Triyanti and M. Gadis, "Pemilihan Supplier Untuk Industri Makanan Menggunakan Metode PROMETHEE," Journal of Logistics and Supply Chain Management, vol. 1, pp. 83-92, 2008.

[7] A. Harsono, H. Prassetyo, and N. Arqom, "Metode Pemilihan Pemasok Sayuran di Supermarket dengan Metode AHP dan PROMETHEE," Jurnal Itenas Rekayasa, vol. 13, 2009.

[8] S. Prasanna Venkatesan and S. Kumanan, "Supply chain risk prioritisation using a hybrid AHP and PROMETHEE approach," International Journal of Services and Operations Management, vol. 13, pp. 19-41, 2012.

[9] G. W. Dickson, "An analysis of vendor selection systems and decisions," 1996.

[10] O. F. Althuwaynee, B. Pradhan, H.-J. Park, and J. H. Lee, "A novel ensemble bivariate statistical evidential belief function with knowledge-based analytical hierarchy process and multivariate statistical logistic regression for landslide susceptibility mapping," Catena, vol. 114, pp. 21-36, 2014. 